\title{
A new, harmless, high-throughput endosperm-based DNA extraction method for wheat
}

\author{
Zhihui Ma ${ }^{1,2}$ (iD) Yuquan Wang ${ }^{1}$ Wenhui Wei ${ }^{1}$ Zhengang $\mathbf{R u}^{{ }^{*}}$ \\ ${ }^{1}$ Henan Institute of Science and Technology, Xinxiang, China. 453003, Xinxiang, China. E-mail: rzgh58@yeah.net. "Corresponding author. \\ ${ }^{2}$ Henan University of Science and Technology, Department Luoyang Key Laboratory of Crop Genetic Improvement \& Germplasm \\ Enhancement, Luoyang, China. \\ ABSTRACT: In this study, a non-destructive, high-throughput, endosperm-based DNA extraction method was developed. To verify the non- \\ destructive nature of this method, a germination test was performed on 288 seeds after sampling their endosperm, which gave a seedling \\ emergence rate that was higher (97.6\%) than that of the control group (92\%). To confirm the feasibility of the new method, DNA was extracted \\ from plants of a $B C_{1} F_{2}$ population by two different methods, namely, from endosperm using our rapid, high-throughput method (ER-DNA) \\ and from young leaves emerging from the same sampled seed using the CTAB method (LC-DNA). The ER-DNA was undetectable by agarose \\ gel electrophoresis, but was found to be an adequate replacement for $L C$-DNA for the amplification and detection of simple sequence repeats \\ (SSRs). Further analysis revealed that ER-DNA was generally suitable for the generation of specific 500-750-bp fragments, but not for the \\ amplification of 1,000-2,000-bp fragments. Our rapid, high-throughput method therefore has no deleterious effects on wheat seeds and yields \\ DNA for SSR genotyping that is a suitable alternative to traditionally obtained DNA. \\ Key words: Wheat, Triticum aestivum, SSR, Segregation population.
}

Um método de extração de DNA novo, inofensivo e de alto teor de endosperma para o trigo

RESUMO: Neste estudo, foi desenvolvido um método de extração de DNA não destrutivo, de alto débito e endosperma. Para verificar a natureza não destrutiva deste método, um teste de germinação foi realizado em 288 sementes após a amostragem do endosperma, o que deu uma taxa de emergência de plântulas maior (97,6\%) do que a do grupo controle (92\%). Para confirmar a viabilidade do novo método, o DNA foi extraido de plantas de uma população de BC1F2 por dois métodos diferentes, a saber, do endosperma usando nosso método rápido de alto rendimento (ER-DNA) e de folhas jovens que emergem da mesma semente amostrada usando o método CTAB (LC-DNA). $O$ ER-DNA foi indetectável por eletroforese em gel de agarose, mas foi encontrado como uma substituição adequada para LC-DNA para a amplificação e detecção de repetições simples de seqüência (SSRS). Uma análise posterior revelou que o ER-DNA era geralmente adequado para a geração de fragmentos especificos de 500-750 pb, mas não para a amplificação de fragmentos de 1.000-2.000 pb. Nosso método rápido e de alto débito, portanto, não tem efeitos deletérios sobre as sementes de trigo e produz DNA para a genotipagem de SSR que é uma alternativa adequada ao DNA obtido tradicionalmente.

Palavras-chave: Trigo, Triticum aestivum, extração de DNA, endosperma.

\section{INTRODUCTION}

Under natural conditions, seed is the first tissue with the potential to become a mature plant. Consequently, extracting DNA from seeds may serve as a useful foundation for early DNA detection. In plant breeding programs, the extraction of DNA from seeds using marker-assisted selection technology can eliminate undesirable seeds before sowing to reduce workload and cost. Similarly, the development of populations for genetic research always requires considerable time and effort for genotype selection and the addition of new generations; consequently, the extraction of DNA from seeds for early detection of traits is an important and very useful way to improve the efficiency of this process. Such an approach is worthless, however, if the seeds do not grow normally after the DNA extraction.

In theory, the main function of wheat endosperm is to supply nutrients to the developing embryo; consequently, the removal of a very small amount of endosperm should not affect this function. In addition, the wheat embryo and wheat endosperm are genetically identical other than ploidy level. Cutting off a small piece of endosperm instead of an embryo or leaf for DNA extraction is thus acceptable 
for genetic analysis and does not prevent the seed from developing into a mature plant.

A05 and BNS366, developed by the Wheat Centre of the Henan Institute of Science and Technology, China, are superior inbred lines of potential value for wheat hybrid breeding. These two lines have different genetic backgrounds and agronomic characteristics. This situation is advantageous when selecting materials to generate a segregating population for genetic research, as genetically similar individuals in such a population are difficult to distinguish. A05 and BNS366 were therefore used to establish a $\mathrm{BC}_{1} \mathrm{~F}_{2}$ population, with the resulting seeds chosen as materials for this study.

The objective of the present study was to develop and evaluate a method for extracting DNA from wheat seeds. To be useful, the method must be simple to follow, high-throughput, inexpensive, non-destructive to seeds, and yield DNA suitable for PCR. To analyse the effect of this method on seeds, we recorded seedling emergence rates. To verify the feasibility of DNA extraction from wheat seeds as an alternative to extraction from wheat leaves, we analysed both endosperm- and leaf-derived DNA using polymorphic simple sequence repeat (SSR) primers.

Numerous attempts have been made to extract DNA during early stages of plant development. For example, HILL-AMBROZ et al. (2002) developed a method for extracting DNA from germinating wheat seedlings in 96-well plates without damaging the seedlings. RICARD et al. (1983) extracted mitochondrial DNA from wheat embryos. ABD-ELSALAM et al. (2011) extracted DNA from germinated seed but used the entire seed. GUPTA et al. (2012) reported the extraction of DNA from imbibed seeds of four plant species including wheat; however, the treated seeds were not tested for germination. KANG et al. (2014) reported a half-seed method for DNA extraction of 12 plant species, including wheat, in which the germination rate of the remaining half seed was unaffected only in rice. POST et al. (2003) developed a method to extract endosperm DNA from dry barley seed using a special drill, but the seed coat was damaged in the process. PAPAZOVA et al. (2005) carried out a real-time PCR analysis of maize that included DNA extraction from both embryo and endosperm. MUTOU et al. (2014) reported the establishment of a method to evaluate seed quality by DNA extraction from rice endosperm. LIANG et al. (2016) presented a half-seed method to extract DNA from rice endosperm using 96-well plates. ZHENG et al. (2015) used special equipment to isolate DNA from cotton seeds; the DNA extraction proved to be nondamaging, and $88 \mathrm{BC}_{1} \mathrm{~F}_{1}$ and $36 \mathrm{BC}_{2} \mathrm{~F}_{1}$ individuals were selected as materials.

DNA extraction from seeds has additionally been reported for many other plant species, including broccoli (VAN DEYNZE et al. 2006), canola (MIDDLETON et al. 2003), carrot (VAN DEYNZE et al. 2006), common bean (INCE et al. 2011), cowpea (SHARMA et al. 2011), grapevine (RATHNAYAKE et al. 2014), groundnut (ROOMI et al. 2013), lettuce (VAN DEYNZE et al. 2006), melon (VAN DEYNZE et al. 2006), mothbean (SHARMA et al. 2011), mungbean (SHARMA et al. 2011), nuts (AKKAK et al. 2008), onion (VAN DEYNZE et al. 2006), pepper (INCE et al. 2011; VAN DEYNZE et al. 2006), radish (VAN DEYNZE et al. 2006), sesame (SHARMA et al. 2011), soybean (INCE et al. 2011; SHARMA et al. 2011; KING et al. 2014; AL-AMERY et al. 2016), squash (VAN DEYNZE et al. 2006), sweet corn (VAN DEYNZE et al. 2006), tomato (INCE et al. 2011; VAN DEYNZE et al. 2006), and watermelon (VAN DEYNZE et al. 2006).

Compare with previous research, the new DNA extraction method own several advantages at the same time. In this study, the endosperm of dry wheat seeds were selected as the basic material for DNA extraction, so the DNA can be extracted at the earliest stage. After the process, the wheat seeds can normally germinate and seedling emergence, so this method was harmless. And then, using this method, wheat seeds can be extract DNA of high quality in batch mode. Besides, the segregation populations were selected as the experimental samples and SSR markers were selected as one of detect method, so this new method have great practical value. At last, more strategies were used to detect and measure the DNA quality of new method, so the application range was more specific.

\section{MATERIALS AND METHODS}

\section{Polymorphism analysis}

A total of 99 SSR primers from 21 chromosomes were selected to analyse polymorphisms between A05 and BNS366.

\section{Establishment of populations}

BNS366, as the recurrent parent, was crossed with $\mathrm{A} 05$ to establish a $\mathrm{BC}_{1} \mathrm{~F}_{1}$ population. Seeds of the $\mathrm{BC}_{1} \mathrm{~F}_{2}$ population used in this study were acquired by selfing of the $\mathrm{BC}_{1} \mathrm{~F}_{1}$ population. Molecular identification of each plant was carried out using 10 polymorphic SSR markers. 


\section{DNA extraction from wheat endosperm}

DNA was extracted from wheat seeds according to the following protocol. First, dry wheat seeds were soaked for $10 \mathrm{~min}$ in water at room temperature $\left(25^{\circ} \mathrm{C}\right)$ and then allowed to dry on filter paper. When the seed coat had loosened on the back of the wheat seed, an incision was made in the seed coat with a scalpel. Approximately $0.4 \mathrm{mg}$ of tissue was excised from the wheat endosperm (Figure 1) and transferred to a 96-well plate. Following this excision, the seed was transferred to a 96-well deep-well plate, with the seed carefully positioned to ensure one-to-one correspondence between its location and that of its excised endosperm tissue in the 96-well plate. After addition of $100 \mu 1$ of $0.1 \mathrm{M}$ $\mathrm{NaOH}$ to each well of the 96-well plate followed by incubation at $99^{\circ} \mathrm{C}$ for $12 \mathrm{~min}, 100 \mu \mathrm{l}$ of TE $(0.01$ $\mathrm{M}$ Tris base and 0.001 M EDTA, pH 2.0) was added to balance the $\mathrm{pH}$. The resulting mixtures were then used as DNA templates for PCR.

The following labelling scheme was used to keep track of endosperm DNA and seed samples. Each 96-well plate and corresponding 96-well deepwell plate was designated as 1,2 , or 3 , with the labels A1 to H12 used to distinguish different positions on the same plate. For example, 2-D10 was used to refer to the seed and the DNA from its endosperm located in row D column 10 on 96-well plate 2 and 96-well deep-well plate 2, respectively. Finally, the letters E and $\mathrm{L}$ were used to distinguish DNA samples isolated by different methods. For example, 1E-B4 means that the DNA sample was extracted from endosperm by the above-described rapid method, whereas $1 \mathrm{~L}-$ B4 was used to designate DNA extracted by the cetyltrimethylammonium bromide (CTAB) method (see below) from young leaves developing from the corresponding seed.

\section{Seed germination rate}

To evaluate the effect of endosperm sampling on seed germination, we performed germination tests on three replications of 96 seeds that had been subjected to DNA extraction from endosperm. As a control, we used 301 intact seeds soaked for $10 \mathrm{~min}$ in water. All seeds in control (CK) and treatment groups were transferred to wet filter paper and incubated in a climate chamber at $20{ }^{\circ} \mathrm{C}$ under a $15-\mathrm{h} / 9-\mathrm{h}$ day/night photoperiod. Seeds from the treatment groups were arranged according to sample number, whereas control group seeds were ordered randomly. The seedling emergence rate was recorded 15 days after sowing.

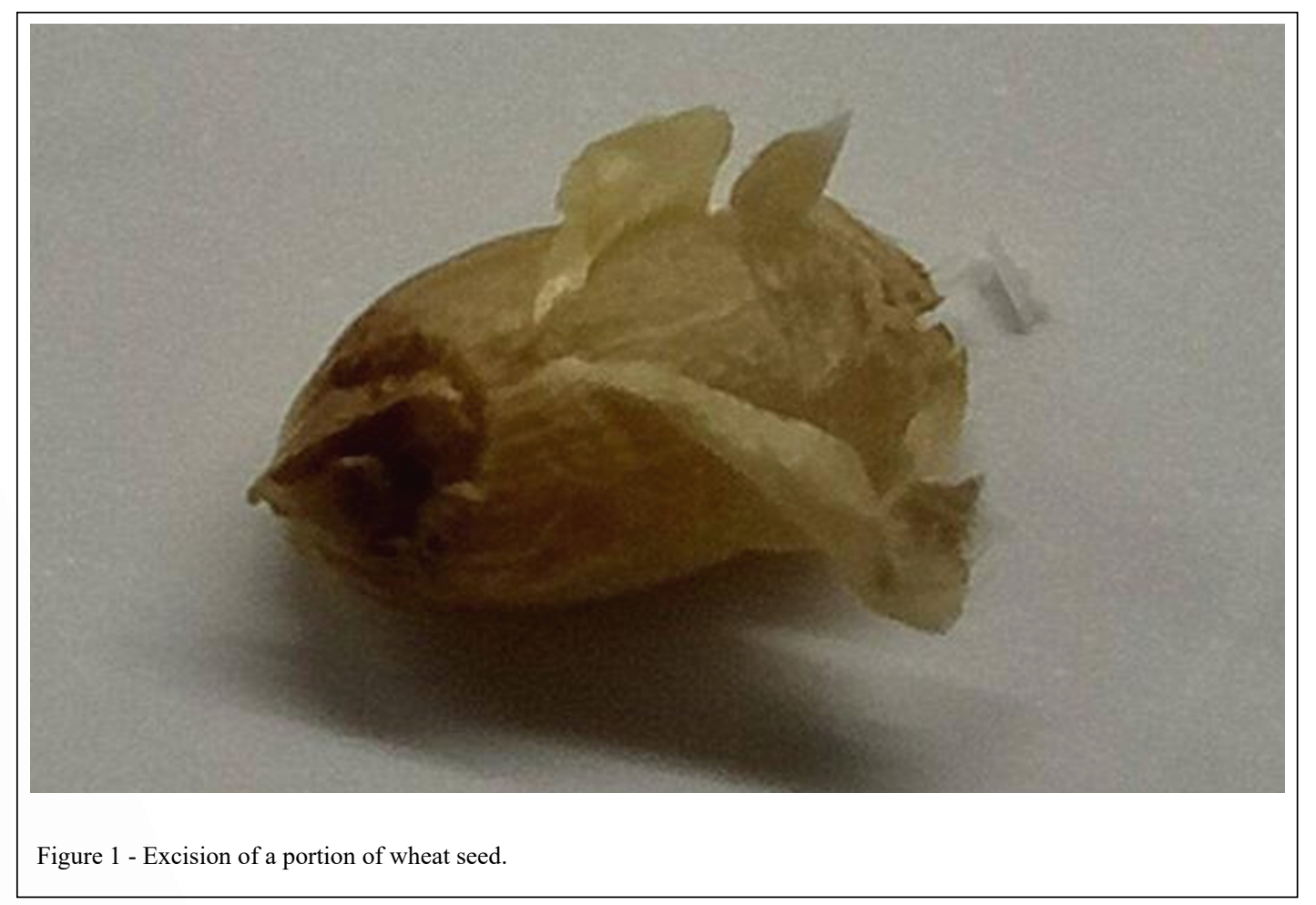

Ciência Rural, v.49, n.9, 2019. 


\section{DNA extraction from wheat leaves}

The CTAB method was used to extract DNA from wheat leaves (LC-DNA) following the method described by POREBSKI et al. (1997). The extracted DNA was checked for concentration and purity. To compensate for several cases in which no DNA was obtained because the seeds failed to germinate, an equivalent volume of TE was substituted for the missing LC-DNA prior to SSR detection.

\section{PCR amplification}

Each reaction mixture for amplification of SSR loci contained $1 \mu 1$ template (50 ng DNA), $2 \mu 1$ each of forward and reverse primers, $5 \mu 1$ of $2 \times$ Es Taq MasterMix (www.cwbiotech.com), and $2 \mu$ l distilled deionised water. PCR cycling conditions were as follows: $94{ }^{\circ} \mathrm{C}$ for $3 \mathrm{~min}$, followed by 35 cycles of $94{ }^{\circ} \mathrm{C}$ for $30 \mathrm{~s}, 55^{\circ} \mathrm{C}$ for 30 (or more) s, and $72{ }^{\circ} \mathrm{C}$ for $30 \mathrm{~s}$, with a final extension step of $72{ }^{\circ} \mathrm{C}$ for $5 \mathrm{~min}$. The $55{ }^{\circ} \mathrm{C}$ extension time was increased according to the length of the expected PCR product, i.e., by approximately $1 \mathrm{~min}$ for each additional $1,000 \mathrm{bp}$.

\section{Polyacrylamide gel electrophoresis (PAGE) and agarose gel electrophoresis \\ PCR amplification products were separated} by $6 \%$ PAGE at $170 \mathrm{~V}$ for $1.5 \mathrm{~h}$. The products were visualised by silver staining using $1 \mathrm{~g} \mathrm{l}^{-1}$ silver nitrate for $20 \mathrm{~min}$ at $20{ }^{\circ} \mathrm{C}$ followed by development in a solution of $20 \mathrm{~g} \mathrm{l}^{-1} \mathrm{NaOH}, 0.4 \mathrm{~g} \mathrm{l}^{-1} \mathrm{Na}_{2} \mathrm{CO}_{3}$, and $0.06 \%(\mathrm{w} / \mathrm{v})$ formaldehyde.

SSR banding patterns in the segregating population were analysed and assigned values as follows: ' 1 ' if the banding pattern was the same as BNS366, ' 2 ' if the banding pattern was the same as A05, and ' 3 ' if the banding pattern was a composite of the two parents.

Finally, the amplified DNA was checked for quality by $1 \%$ agarose gel electrophoresis at $110 \mathrm{~V}$ for half an hour followed by staining with Goldview (Solarbio, Beijing, China).

\section{DNA quality comparison of two methods}

In order to evaluate the DNA quality using new method, in this study, four steps had been taken between new method and traditional method. Step 1, measure the DNA concentrations and A260/A280 ratios by spectrophotometer (NanoDrop ND-2000, Thermo). Step 2, 1\% agarose gel electrophoresis (110v, 0.5 hour) was used to show the DNA integrity. Step 3, 6\% polyacrylamide gel electrophoresis $(170 \mathrm{v}$, 1.5 hour) was used to distinguish the gene types of the $\mathrm{BC}_{1} \mathrm{~F}_{2}$ population. Step 4 , used different primers (corresponding with different length PCR Products, 500-750bp,750-1000bp, 1000-2000bp) to estimate the length of DNA.

\section{RESULTS}

Comparison of efficiency between two extraction methods

The CTAB method contain a total of 8 main reagent, $\mathrm{NaOH}, \mathrm{HCl}$, Tris, EDTA, CTAB, chloroform, isoamylol and ethly alcohol. The new method only contain 4 main reagent, $\mathrm{NaOH}, \mathrm{HCl}$, Tris and EDTA. The CTAB method contain 14 necessary steps, but the new method contain 4 necessary steps. The whole process of the CTAB method take about 1.5 hours, the new method take about 20 minutes only. When a large number of samples need be processed, the new method show great advantage by using multibarrelmicropipettor. Based on rough calculations, deal with 1000 samples need less than 8 hours using new method, but more than 56 hours using CTAB method.

\section{The effect of DNA extraction on wheat seeds \\ Control group replicates CK-1, CK-2,} and CK-3 collectively contained 301 wheat seeds. In replicate CK-1, 94\% of seeds (94 seeds) developed into seedlings, while 5\% (5) exhibited no significant germination-related changes. The radicle of the other remaining seed grew normally but could not penetrate the seed coat. In the CK-2 group, $92 \%$ of seeds (93) developed into seedlings and 8\% (8) failed to germinate. In the CK-3 group, $90 \%$ of seeds (90) formed seedlings, while $8 \%$ (8) did not germinate. Two seeds developed normal radicles, but the young bud was unable to penetrate the seed coat. The first treatment-group replicate comprised 96 wheat seeds, of which $97.9 \%$ (94) developed into seedlings and $2.1 \%$ ( 2 seeds: $1-\mathrm{B} 12$ and $1-\mathrm{G} 4)$ showed no significant evidence of germination. The second replicate group contained 96 wheat seeds; $97.9 \%$ of these (94 seeds) grew into seedlings, while $2.1 \%$ (2 seeds: 2 -A 1 and 2-B12) did not germinate. Of the 96 wheat seeds in the third treatment replicate, $97 \%$ (93) developed into seedlings and 3\% (3 seeds: 3-A12, 3-C9, and 3-D4) did not germinate significantly (Table 1 ). According to our statistical analysis, the emergence rate of the treatment group was significantly higher than that of the control group $(\mathrm{P}<0.01)$.

Comparison of DNA quality and concentration between the two extraction methods

Concentrations of LC-DNA, i.e., the DNA extracted from wheat leaves by the CTAB 
Table 1 - Seedling rate of the seeds which were used to extract DNA from endosperm.

\begin{tabular}{|c|c|c|c|c|c|}
\hline Groups & Number of seeds & Seedlings number & Seedling rate & $\begin{array}{l}\text { Seeds which were failed } \\
\text { to seedling }\end{array}$ & Reason of failing to seedling \\
\hline ck-1 & 100 & 94 & 0.94 & & $\begin{array}{l}\text { Five seeds failed to germinate, one } \\
\text { seed failed to break through seed coat }\end{array}$ \\
\hline ck-2 & 101 & 93 & 0.92 & & Eight seeds failed to germinate \\
\hline ck-3 & 100 & 90 & 0.9 & & $\begin{array}{l}\text { Eight seeds failed to germinate, two } \\
\text { seeds failed to break trough seed coat }\end{array}$ \\
\hline 1 & 96 & 94 & $97.9 \%$ & $1-\mathrm{B} 12$ and $1-\mathrm{G} 4$ & Two seeds failed to germinate \\
\hline 2 & 96 & 94 & $97.9 \%$ & 2-A1 and 2-B12 & Two seeds failed to germinate \\
\hline 3 & 96 & 93 & $96.9 \%$ & 3-A12,3-C9 and 3-D4 & Three seeds failed to germinate \\
\hline
\end{tabular}

method, ranged from 1,500 to $5,000 \mathrm{ng} \mu \mathrm{l}^{-1}$ with one exception: the concentration of 1L-H9, which was $478 \mathrm{ng} \mu \mathrm{l}^{-1}$. ER-DNA, corresponding to DNA extracted from wheat endosperm using our newly developed, rapid method, ranged in concentration from

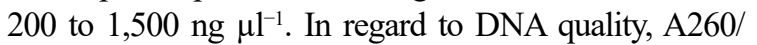
A280 ratios of 23 samples of LC-DNA varied between 1.8 and 2.0, with one sample having an A260/A280 ratio of 1.63. Among ER-DNA samples, 20 had A260/A280 ratios between 1.0 and 1.5, while three had a ratio of approximately 2.0 and one had a ratio of 4.37. Agarose gel electrophoresis of 87 LC-DNA samples yielded single, distinct bands corresponding to DNA fragments larger than 2,000 bp. Among the remaining LC-DNA samples, diffuse bands were associated with six samples (1-A10, 1-B1, 1-B2, 1-D4, 1-H9, and 1-12) and no bands were evident for three samples (1-B12, 1-G4, and 1-H9). No bands were observed upon electrophoresis of any of the 36 ER-DNA samples.

\section{Screening for polymorphic SSR primers}

A total of 99 SSR primers randomly selected from 872 SSR primers reported by SOMERS et al. (2004) and distributed on 21 chromosomes were screened between the parents, B36 and A05, using DNA extracted from young leaves by the CTAB method. Of the tested primers, 10 (barc174, barc56, barc164, barc55, barc158, wmc24, gwm480, wmc169, gwm539, and cfd84) were polymorphic between the two parents (Figure 2).

\section{Detection of SSRs in the two groups of DNA}

The above-mentioned 10 polymorphic primers were used to genotype 190 DNA samples extracted from 96 wheat seeds and 94 young leaves. On the basis of two PCR replications, no difference was found in most genotypes between the two different DNA extraction methods (Table 2). Upon repeating the PCR amplifications once more to identify the actual genotypes, we confirmed that all genotypes were identical between the two extraction methods (Table 2). With respect to identifying actual genotypes, we found that genotypes of LC-DNA were more likely to be misread than those of ER-DNA. We thus believe that ER-DNA is a suitable replacement for LC-DNA in SSR-based analyses. Part of the genotyping are shown in figure 3 .

\section{Testing genetic purity of experimental seeds}

Ensure the purity of crop seeds was a significant step to agricultural production. In this study, the truthfulness of the experimental seeds related to the conclusion of this study. The results of SSR detection show that the gene types of all 94 seeds were from A05 and/or B36. As BC1F2 population in this study, the separation ratio of three types ("2", "3" and " 1 " in order) of every SSR marker should be $1: 2: 5$. After chi-square tests, the separation radios of 7 in 10 SSR markers (barc174, barc56, barc164, barc158, gwm480, wmc169 and gwm539 in order) were accordance with $1: 2: 5\left(\chi^{2}\right.$ $=2.613,1.379,3.770,1.174,2.740,2.681$ and 3.804 in order, $\chi 20.05,2=5.991)$. However three other SSR markers (barc55, wmc24 and cfd84) didn't show the theoretical separation ratio.

\section{Limitations on the use of ER-DNA}

Because target-fragment lengths of SSR primers are always less than $500 \mathrm{bp}$, we selected seven other primers with longer target fragments to determine size limitations on the use of ER-DNA for PCR. When expected PCR product sizes were between 500 and $750 \mathrm{bp}$, the anticipated bands were 


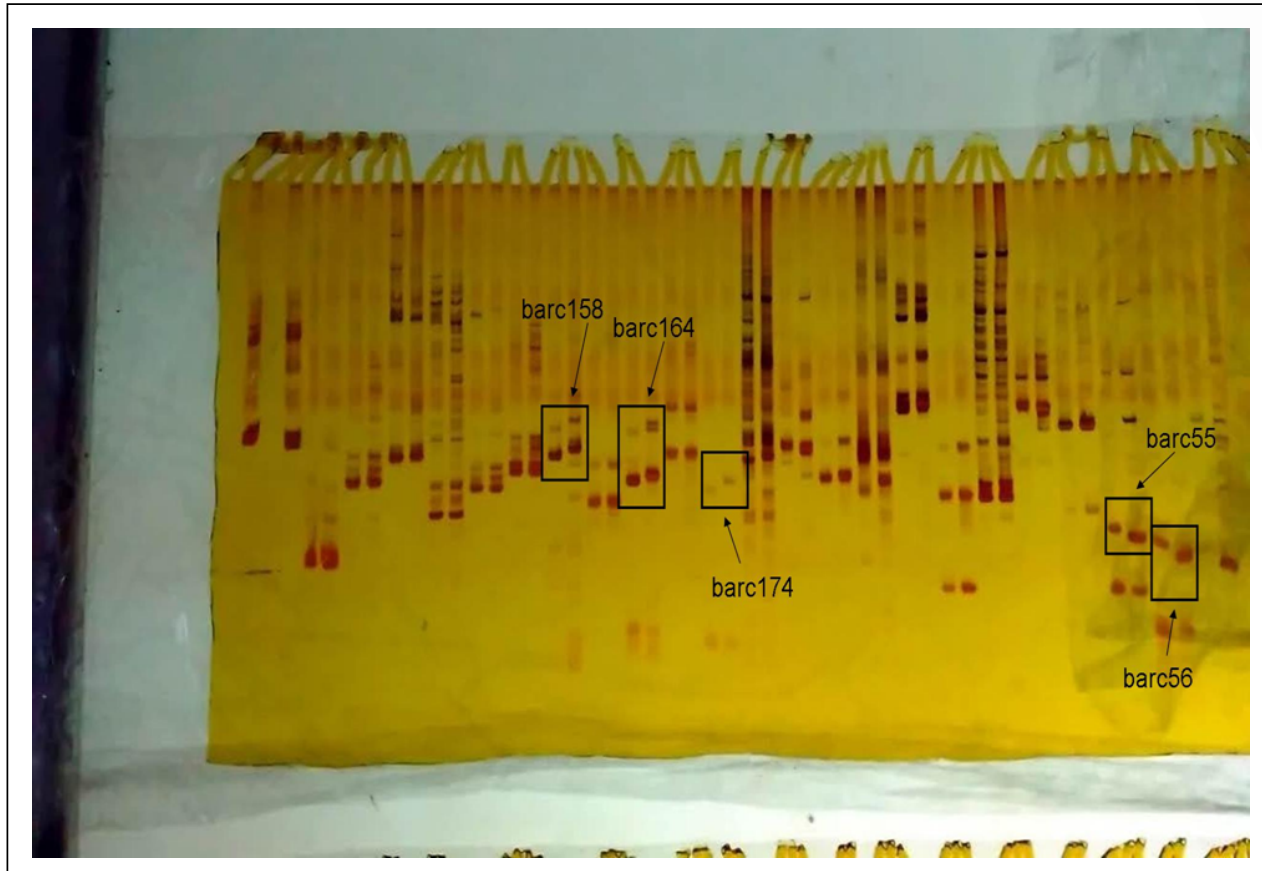

Figure 2 - Polyacrylamide gel electrophoresis for screening of polymorphic SSR primers.

only obtained from a few ER-DNA samples (7 of 24) by PCR, whereas 19 of 24 LC-DNA samples yielded the specific band. No distinct bands were obtained from ER-DNA when desired PCR product sizes ranged from 1,000 to $2,000 \mathrm{bp}$; in contrast, these fragments were successfully amplified from most LC-DNA samples. In this study, LC-DNA was therefore found to be more suitable than ER-DNA for amplifying longer target regions.

\section{DISCUSSION}

According to our germination test results, the protocol used to extract DNA from seed endosperm in this study was not harmful to seeds; in fact, it improved the emergence rate, as emergence rates of the treatment group were higher than those of the CK group. A few seeds in the CK group failed to germinate because the developing shoot could not penetrate the seed coat, which suggests that mechanical damage to the seed coat is beneficial to germination. Aside from germination failures due to seed coats, the treatment group still contained a smaller percentage of dormant seeds compared with the CK group and exhibited a significantly higher emergence rate $(\mathrm{P}<0.05)$. Consequently, separation of part of the seed coat from the endosperm and/or removal of a small piece of endosperm were other possible beneficial factors for germination and emergence. Some studies have shown that lack of permeability to water or air, resistance to mechanical penetration, and the presence of chemical substances in the seed coat can inhibit germination (MIYAMOTO et al. 1961; AMANO et al. 2002).

Some reports (NANDAKUMAR et al. 2004; BORA et al. 2016) show that SSR marker were used to identify the seed purity. In this study, all of 10 SSR markers show all gene types of 94 seeds were from the parents. And more or less, every seed (except "1-C1") own different gene types among 10 SSR markers. So we inferred that the experimental seeds were hybrid offspring of A05 and B36, there were no pollen pollution in every generation. Based the design of this study and Mendel's law, the gene types of every primer should fit suitable separation radio. In order to prove the experimental seeds were $\mathrm{BC}_{1} \mathrm{~F}_{2}$ population, the chi-square tests were performed. The results of 7 primers show that the experimental seeds were real $\mathrm{BC}_{1} \mathrm{~F}_{2}$ population. Forming reason of segregation distortion were lethal genes or other segregation distortion factors (NASUDA et al. 1998; MARAIS et al. 2001). CHU et al (2006) had reported that a hybrid 
Table 2 - Results of SSR detection.

\begin{tabular}{|c|c|c|c|c|c|c|c|}
\hline $\begin{array}{l}\text { Names of } \\
\text { SSR } \\
\text { primers }\end{array}$ & $\begin{array}{c}\text { DNA } \\
\text { groups }\end{array}$ & $\begin{array}{l}\text { Number of } \\
\text { seeds/seed } \\
\text { lings }\end{array}$ & $\begin{array}{l}\text { Number of } \\
\text { readable } \\
\text { genetypes }\end{array}$ & $\begin{array}{l}\text { Number of } \\
\text { plants extracted } \\
\text { DNA by two } \\
\text { methods }\end{array}$ & $\begin{array}{c}\text { Number of same } \\
\text { genetypes } \\
\text { between two } \\
\text { types of DNA }\end{array}$ & $\begin{array}{l}\text { Number of same } \\
\text { genetypes between } \\
\text { two types of } \\
\text { DNA, after } \\
\text { identification }\end{array}$ & $\begin{array}{l}\text { Number of } \\
\text { misreading } \\
\text { genetypes }\end{array}$ \\
\hline \multirow{2}{*}{ barc174 } & LC-DNA & 94 & 94 & \multirow{2}{*}{94} & \multirow{2}{*}{88} & \multirow{2}{*}{94} & 4 \\
\hline & ER-DNA & 96 & 96 & & & & 2 \\
\hline \multirow{2}{*}{ barc56 } & LC-DNA & 94 & 94 & \multirow{2}{*}{94} & \multirow{2}{*}{94} & \multirow{2}{*}{94} & 0 \\
\hline & ER-DNA & 96 & 96 & & & & 0 \\
\hline \multirow{2}{*}{ barc164 } & LC-DNA & 94 & 94 & \multirow{2}{*}{94} & \multirow{2}{*}{94} & \multirow{2}{*}{94} & 0 \\
\hline & ER-DNA & 96 & 96 & & & & 0 \\
\hline \multirow{2}{*}{ barc55 } & LC-DNA & 94 & 94 & \multirow{2}{*}{94} & \multirow{2}{*}{94} & \multirow{2}{*}{94} & 0 \\
\hline & ER-DNA & 96 & 96 & & & & 0 \\
\hline \multirow{2}{*}{ barc158 } & LC-DNA & 94 & 94 & \multirow{2}{*}{94} & \multirow{2}{*}{93} & \multirow{2}{*}{94} & 1 \\
\hline & ER-DNA & 96 & 96 & & & & 0 \\
\hline \multirow{2}{*}{ wmc24 } & LC-DNA & 94 & 94 & \multirow{2}{*}{94} & \multirow{2}{*}{93} & \multirow{2}{*}{94} & 1 \\
\hline & ER-DNA & 96 & 96 & & & & 0 \\
\hline \multirow{2}{*}{ gwm480 } & LC-DNA & 94 & 94 & \multirow{2}{*}{94} & \multirow{2}{*}{88} & \multirow{2}{*}{94} & 3 \\
\hline & ER-DNA & 96 & 96 & & & & 3 \\
\hline \multirow{2}{*}{ wmc169 } & LC-DNA & 94 & 94 & \multirow{2}{*}{94} & \multirow{2}{*}{94} & \multirow{2}{*}{94} & 0 \\
\hline & ER-DNA & 96 & 96 & & & & 0 \\
\hline \multirow{2}{*}{ gwm539 } & LC-DNA & 94 & 94 & \multirow{2}{*}{94} & \multirow{2}{*}{94} & 04 & 0 \\
\hline & ER-DNA & 96 & 96 & & & 94 & 0 \\
\hline & LC-DNA & 94 & 94 & & & & 0 \\
\hline cfd84 & ER-DNA & 96 & 96 & 94 & 94 & 94 & 0 \\
\hline
\end{tabular}

necrosis gene was linked with barc55, so we guess that the existence of segregation distortion region caused the separation radio of the three primers didn't fit the theoretical value. And 7 primers were enough to show the truthfulness of the experimental seeds.

Our evaluation of DNA extracted by the two different methods revealed higher concentrations of LC-DNA than ER-DNA. Given that an A260/A280 ratio of 1.8 to 2.0 indicates high purity, LC-DNA was of higher quality. Because the endosperm-based method did not include a procedure for removing RNA, proteins and sugars, ER-DNA was of lower purity. LC-DNA had good integrity according to the results of agarose gel electrophoresis. Compared with other LC-DNA samples, the DNA extracted from seed 1-H9 was present in a lower concentration and had a smaller A260/A280 ratio; this DNA was undetectable after agarose gel electrophoresis, most likely because of its low concentration and/or low A260/A280 ratio (similar to ER-DNA samples). Because a lowconcentration DNA should still appear as a weak band, the undetectability of this sample was more likely due to the low purity, as some impurities can disturb the binding process between DNA molecules and nucleic acid stain. As implied by the low A260/ A280 ratio, too much protein was present in the DNA sample. Studies have found that some proteins can bind to DNA strands (SHANAHAN et al. 2004; KUZNETSOV et al. 2006; OFRAN et al. 2007; SI et al. 2015); consequently, the binding of excess protein to DNA strands may have interfered with the detection of this sample on the agarose gel.

The screening of seeds for breeding selection was one of the motivations for this study. Although the emergence rates recorded here may differ from those obtained in soil in a real field environment, the complete development of young seedling lines from germinating seeds can be observed and analysed. One of the main conclusions of this study is that DNA extracted from endosperm can replace leaf DNA in SSR-based analyses. This conclusion is supported by evidence obtained using leaf DNA selected as a control from the same plant and our abundant data (including approximately 300 wheat seeds, 10 polymorphic markers from 99 SSR primers, 94 pairs of DNA samples. and 940 pairs of SSR genotypes). 


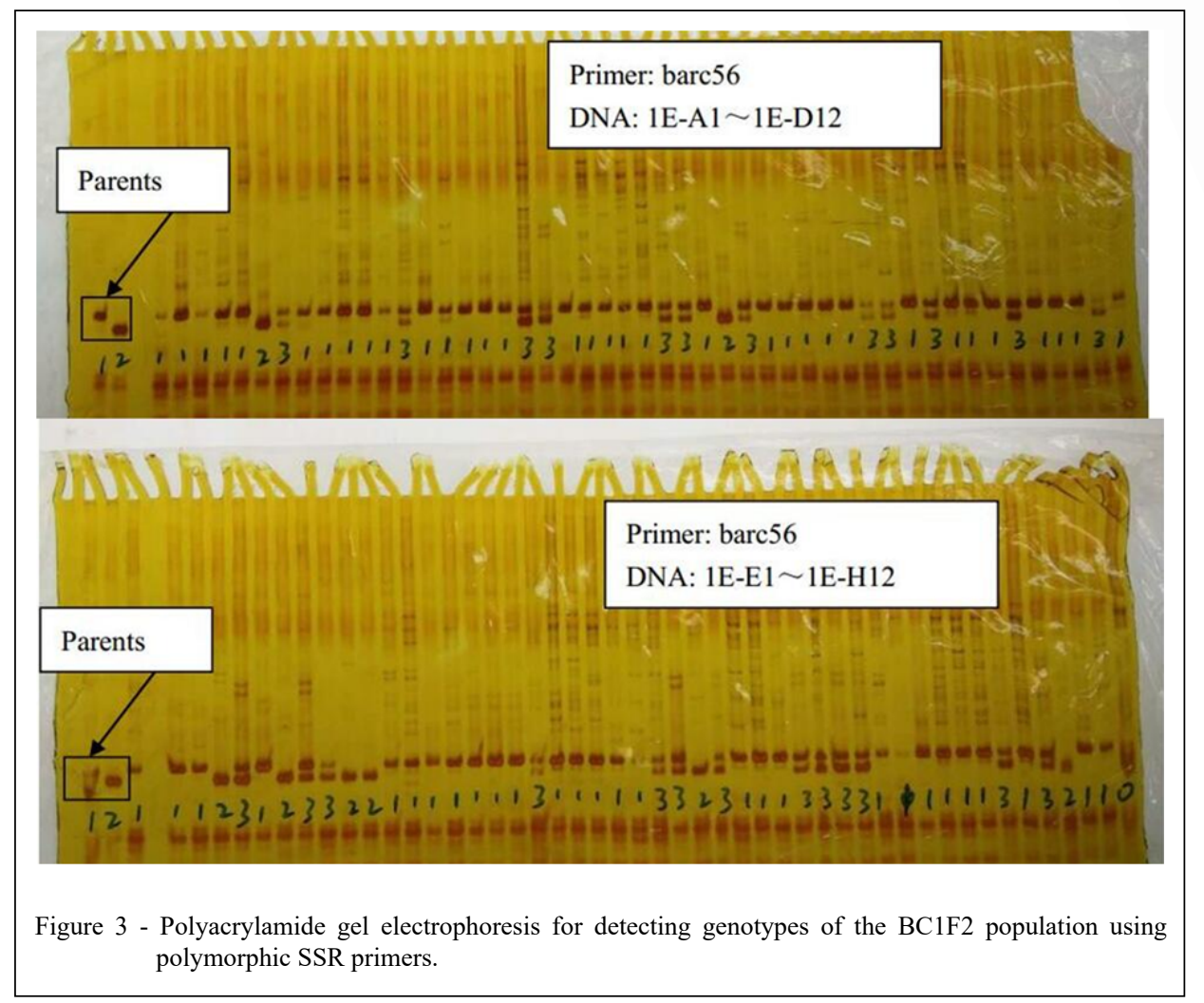

To find a DNA extraction method in early stage of plant, some studies (HILL-AMBROZ et al. 2002; SHARMA et al. 2011; ABD-ELSALAM et al. 2011) suggest that bud or young leaves can be used to extract DNA. However, compare with this study, the stages of plant were too late. It will be about one week from dry seed to young leaves. And if you want to sow thesis seeds, it is very hard for storage once the seed germinated. Some other researches (KANG et al. 1998; POST et al. 2003; KING et al. 2014; LIANG et al. 2016) had given similar plans compare with this research. However they still cut a too big piece of seed (one tenth or half of one seed), sometimes they did not even consider the harmful of embryo. Besides, the gene types of seed coat might not be same to the embryo (obtain seeds by hybridization), many researchers pay no attention to this point.

\section{CONCLUSIONS}

In this study, we have demonstrated that our new method of extracting DNA from endosperm has no deleterious effect on seedling emergence and that the resulting ER-DNA can replace LC-DNA in SSR genotyping analyses. Compared with LC-
DNA, however, ER-DNA is of lower concentration and purity. In addition, its application is limited to amplification of fragments shorter than $750 \mathrm{bp}$.

\section{DECLARATION OF CONFLICT OF INTERESTS \\ The authors declared no potential conflicts of interest with respect to the research, authorship, and/or publication of this article.}

\section{REFERENCES}

ABD-ELSALAM, K., et al. An optimized protocol for DNA extraction from wheat seeds and Loop-Mediated Isothermal Amplification (LAMP) to detect fusarium graminearum contamination of wheat grain. International Journal of Molecular Sciences, 12, 3459-3472, 2011. Available from: <https://www. ncbi.nlm.nih.gov/pubmed/21747688>. Accessed: Jun. 4, 2017.

AKKAK, A., et al. An efficient DNA-extraction protocol for nut seeds. Journal of Food Quality, 31, 549-557, 2008. Available from: <https://onlinelibrary.wiley.com/doi/full/10.1111 /j.1745-4557.2008.00219.x>. Accessed: Jul. 4, 2017.

AL-AMERY, M., et al. Nondestructive DNA extraction techniques for soybean (Glycine Max) seeds. Journal of Crop Improvement, 30, 165-175, 2016. Available from: <https://www.tandfonline. 
com/doi/full/10.1080/15427528.2015.1136366>. Accessed: Jul. 4, 2017. doi: $10.1080 / 15427528.2015 .1136366$.

AMANO, Y.; TORADA, A. Breeding of white-grained wheats for Japan. Euphytica, 126, 83-88, 2002. Available from: <https:// insights.ovid.com/euphytica/euph/2002/12/610/breeding-whitegrained-wheats-japan/13/00009267>. Accessed: Jul. 4, 2017.

BORA, A., et al. Assessment of genetic purity in rice (Oryza sativa L.) hybrids using microsatellite markers. Biotech, 6, 1-7, 2016. Available from: <https://link.springer.com/article/10.1007/ s13205-015-0337-y>. Accessed: Jul. 8, 2017.

CHU, C. G., et al. Molecular mapping of hybrid necrosis genes $\mathrm{Ne} 1$ and $\mathrm{Ne} 2$ in hexaploid wheat using microsatellite markers. Theoretical and Applied Genetics, 112, 13741381, 2006. Available from: <https:/www.ncbi.nlm.nih.gov/ pubmed/16518615>. Accessed: Jul. 4, 2017.

GUPTA, R., et al. A simple modified method of DNA extraction from seeds for PCR amplifications. Indian Journal of Agricultural Sciences, 82, 75-77, 2012. Available from: <https:// www.researchgate.net/publication/236278592_A_simple modified_method_of_DNA_extraction_from_seeds_for_PCR_ amplifications>. Accessed: Jul. 9, 2017.

HILL-AMBROZ, K. L., et al. Modified rapid DNA extraction protocol for high throughput microsatellite analysis in wheat. Crop Science , 42, 2088-2088, 2002. Available from: <https:// dl.sciencesocieties.org/publications/cs/articles/42/6/2088>. Accessed: Jul. 9, 2017.

INCE, A. G., et al. The MAGi DNA extraction method for fresh tissues and dry seeds. Journal of Medicinal Plant Research, 5, 5458-5464, 2011. Available from: <https://www.researchgate.net/ publication/267251225_The_MAGi_DNA_extraction_method for_fresh_tissues_and_dry_seeds $>$. Accessed: Jul. 9, 2017.

KANG, H. W., et al. A rapid DNA extraction method for RFLP and PCR analysis from a single dry seed. Plant Molecular Biology Reporter, 16, 90-90, 1998. Available from: <https:// link.springer.com/article/10.1023/A:1007418606098>. Accessed: Jul. 9, 2017.

KING,Z.,ETal. Non-toxic and efficientDNAextractions for soybean leaf and seed chips for high-throughput and large-scale genotyping. Biotechnology Letters, 36, 1875-1879, 2014. Available from: $<$ https://www.researchgate.net/publication/262644187_Nontoxic_and_efficient_DNA_extractions_for_soybean_leaf_and seed_chips_for_high-throughput_and_large-scale_genotyping $>$. Accessed: Jun. 10, 2017.

KUZNETSOV, I. B., et al. Using evolutionary and structural information to predict DNA-binding sites on DNA-binding proteins. Proteins, 64, 19-27, 2006. Available from: $<$ https://www. ncbi.nlm.nih.gov/pubmed/16568445>. Accessed: Jun. 10, 2017.

LIANG, H. B., et al. A high-throughput DNA extraction method from rice seeds. Biotechnology \& Biotechnological Equipment, 30, 32-35, 2016. Available from: <https:/www.tandfonline.com/ doi/pdf/10.1080/13102818.2015.1088401? needAccess $=$ true $>$. Accessed: Jun. 10, 2017. doi: 10.1080/13102818.2015.1088401.

MARAIS, G. F., et al. Evaluation and reduction of Lr19-149, a recombined form of the Lr19 translocation of wheat. Euphytica,
121, 289-295, 2001. Available from: <https://link.springer.com/arti cle/10.1023/A:1012016209287>. Accessed: Aug. 10, 2017.

MIDDLETON, A. T.; STONE E. M. DNA extraction from bulked samples of canola seed and the use of multiplex PCR for detection of adventitious contamination with genetically modified seed. Seed Science and Technology, 31, 487-495, 2003. Available from: $<$ https:// www.ingentaconnect.com/content/ista/sst/2003/00000031/00000002/ art00025>. Accessed: Jul. 4, 2017. doi: 10.15258/sst.2003.31.2.25.

MIYAMOTO, T., et al. Germination inhibitors related to dormancy in wheat seeds. Plant Physiology, 36, 739-746, 1961. Available from: <http://www.plantphysiol.org/content/36/6/739>. Accessed: Jul. 4, 2017.

MUTOU, C., et al. DNA extraction from rice endosperm (Including a protocol for extraction of DNA from ancient seed samples). Cereal Genomics: Methods and Protocols, 1099, 7-15, 2014. Available from: <https://experiments.springernature.com/ articles/10.1007/978-1-62703-715-0_2>. Accessed: Jul. 4, 2017.

NANDAKUMAR, N., et al. Molecular fingerprinting of hybrids and assessment of genetic purity of hybrid seeds in rice using microsatellite markers. Euphytica, 136, 257-264, 2004. Available from: <https:/link.springer.com/article/10.1023/ B:EUPH.0000032706.92360.c6>. Accessed: Jul. 4, 2017.

NASUDA, S., et al. Gametocidal genes induce chromosome breakage in the interphase prior to the first mitotic cell division of the male gametophyte in Wheat. Genetics, 149, 1115-1124, 1998. Available from: <https://www.ncbi.nlm.nih. gov/pubmed/9611219>. Accessed: Sept. 4, 2017.

OFRAN, Y., et al. Prediction of DNA-binding residues from sequence. Bioinformatics, 23, I347-I353, 2007. Available from: $<$ https://www.ncbi.nlm.nih.gov/pubmed/17646316>. Accessed: Sept. 4, 2017.

PAPAZOVA, N., et al. DNA extractability from the maize embryo and endosperm-relevance to GMO assessment in seed samples. Seed Science and Technology, 33, 533-542, 2005. Available from: <https:/www.ingentaconnect.com/content/ista/ sst/2005/00000033/00000003/art00001>. Accessed: Sept. 4, 2017. doi: $10.15258 /$ sst.2005.33.3.01.

POREBSKI, S., et al. Modification of a CTAB DNA extraction protocol for plants containing high polysaccharide and polyphenol components. Plant Molecular Biology Reporter, 15, 8-15, 1997. Available from: <https://link.springer.com/article/10.1007/ BF02772108>. Accessed: Sept. 4, 2017.

POST, R. V., et al. A high-throughput DNA extraction method for barley seed. Euphytica, 130, 255-260, 2003. Available from: $<$ https://link.springer.com/article/10.1023/A:1022863006134>. Accessed: Sept. 4, 2017.

RATHNAYAKE, A. S., et al. High quality DNA obtained from a single seed of vitis vinifera L. using rapid DNA extraction method. American Journal of Plant Sciences, 5, 2023-2030, 2014. Available from: <https://www.researchgate.net/publication/263510721_High Quality_DNA_Obtained_from_a_Single_Seed_of_Vitis_vinifera_L_ Using_Rapid_DNA_Extraction_Method>. Accessed: Sept. 4, 2017.

RICARD, B., et al. DNA synthesis in isolated mitochondria and mitochondrial extracts from wheat embryos, Plant Molecular 
Biology, 12, 167-175, 1983. Available from: <https://link. springer.com/article/10.1007/BF01578376>. Accessed: Jun. 4, 2017.

ROOMI, S., et al. Protocol optimization for deoxyribonucleic acid (DNA) extraction from dried, fresh leaves, and seeds of groundnut (Arachis hypogaea L.). African Journal of Biotechnology, 12, 7070-7073, 2013. Available from: <https:// www.researchgate.net/publication/259827802_Protocol_ optimization_for_DNA_extraction_from_dried_fresh_leaves_ and_seeds_of_groundnut_Arachis_hypogaea_L $>$. Accessed: Jun. $4,201 \overline{7}$.

SHANAHAN, H. P., et al. Identifying DNA-binding proteins using structural motifs and the electrostatic potential. Nucleic Acids Research, 32, 4732-4741, 2004. Available from: <https:// academic.oup.com/nar/article/32/16/4732/1023239>. Accessed: Jun. 4, 2017.

SHARMA, S. N., et al. A modified DNA extraction protocol and its utility in seed genetic purity assessment. Seed Science and Technology, 39, 236-242, 2011. Available from: $\quad<$ https://www.ingentaconnect.com/contentone/ista/ sst/2011/00000039/00000001/art00024>. Accessed: Jun. 4, 2017. doi: 10.15258/sst.2011.39.1.24.

SI, J., et al. An overview of the prediction of protein DNA-binding sites. International Journal of Molecular Sciences, 16, 51945215, 2015. Available from: <https://www.researchgate.net/ publication/273786822_An_Overview_of_the_Prediction_of_Protein DNA-Binding_Sites $>$. Accessed: Jun. 4, 2017. doi: $10.3390 /$ ijms 16035194.

SOMERS, D. J., et al. A high-density microsatellite consensus map for bread wheat (Triticum aestivum L.). Theor Appl Genet, 109, 1105-1114, 2004. Available from: <https://www.ncbi.nlm.nih.gov/ pubmed/15490101>. Accessed: Jun. 12, 2017.

VAN DEYNZE, A.; STOFFEL K. High-throughput DNA extraction from seeds. Seed Science and Technology, 34, 741-74, 2006.

ZHENG, X., et al. Non-destructive high-throughput DNA extraction and genotyping methods for cotton seeds and seedlings. Biotechniques, 58, 234-243, 2015. Available from: $<$ https://www. future-science.com/doi/pdf/10.2144/000114286>. Accessed: Jun. $12,2017$. 